\title{
Life and Personality of Queen Esther and Rani Lakshmibai: A Research
}

\author{
Crispine Shiny, D. David Wilson
}

\begin{abstract}
Tommy Tenney in the book, Hadassah The girl who became Queen Esther describes about the life history of Queen Esther and her struggle to win over the cruel plot of Haman. Shahana Dasgupta in her book, Rani Lakshmibai the Indian heroine describes Rani Lakshmibai as a freedom fighter for Jhansi against the British rule. The Queen of Persia, Esther reigned over 127 provinces starting from Ethiopia to India. She is a brave woman who took a stand for Jews in a crucial time. Through her fasting and spiritual warfare she could able won the favour of King Xerxes. Because of her leading nature the Jews killed the Agagites. Lakshmibai, The Rani of Jhansi was the queen of the Maratha-ruled princely state of Jhansi in India. She was one of the leading personality of the Indian rebellion of 1857, and a symbol of resistance to British rule in India. The name of Rani Lakshmibai in Indian History is synonymous with heroism and courage. In extremely adverse circumstance she staunchly refused to give in to the demands of the formidable opponents, the Britishers; fought them bravely with only a handful of allies and finally sacrificed her life in the battlefield.

Esther and Lakshmibai's biography is similar in many ways like the change of namebefore marriage and after marriage. Hadassah as Esther and Manu as Lakshmibai. Both of them lost their mother in the childhood and raise up by their father. In the

case of Esther she was brought up by Mordecai While Lakshmibai was brought up by Moropant. Esther fought for Jews to live in Persia and Lakshmibai fought for Marathas to live in Jhansi. This paper intends to do a comparative study on Queen Esther of Persia and Rani Lakshmibhai of Jhansi in India. The paper also portrays how both the women took a strong decision to save their tribe or people from the enemies.
\end{abstract}

\section{INTRODUCTION}

Literature is one of the fine arts that employ language as a medium of expression. It is the expression of human feelings, emotions, sufferings and joy. Superior literature is never outdated and there is no limitation of place and time to it. Hence, it is permanent. It is also universal, in the sense that it appeals to the readers across national or linguistics boundaries. Though language and culture differ, human sentiments remain essentially the same in every type of literature of the world.

Comparative literature involves the study of texts across cultures, that is interdisciplinary and it is concerned with patterns of connection in literatures across time and space. In Comparative literature, a reader may be impelled to follow up what appear to be similar between texts or author from different cultural contexts. Mathew Arnold in his Inaugural Lecture at Oxford in 1857 said: illustration. No single event, no single literature is adequately comprehended except in relation to other event,

Revised Manuscript Received on July 18, 2019.

Crispine Shiny, Ph.D Scholar, Karunya Institute of Technology and Sciences, Coimbatore. T.N, India.

Dr. D. David Wilson, Associate Professor, Karunya Institute of Technology and Sciences, Coimbatore. T.N, India.
"Everywhere there is connection, everywhere there is

to other literatures" (Comparative Literature, pg: 1). In this context, Persian literature is compared with Indian literature. Persians came to India for trade and commerce. The age of the Khaljis was a great period for Persian literature in India (Facets of Indian culture, pg: 438). During the reign of King Xerxes India was one of the provinces among the 127 provinces of Xerxes.

According to Alma Dawson Christian fiction applies biblical ethics and morality to life issues. These are stories of complex problems and the trials of the Christian individual whose faith is tested by the challenges and promises of the real world (2005: 45). The story of Hadassah is a part of Christian fiction. Hadassah's faith was tested when she was about to meet the King without his invitation. Still she stood strong and won her case.

Hadassah: The girl who became Queen Esther is a fiction that deals with the biblical character Esther and her life. Tommy Tenney is an American preacher and author. Tenney has written over thirty books and his writings have been translated into more than forty languages. His works have been nominated for many awards including the Gold Medallion Award and Retailers Book of the Year. He is the author of the multimillion selling booksThe God Chaser series, God's eye view, and God's dream team. ("Tommy Tenney").

Shahana Dasgupta, a graduate from Delhi University, holds an LLM degree from the University of Michigan, Ann Arbor, USA. She has been living in Berlin since 1986 and authoring four Rupa publicationsThis India, Razia: The People's Queen, Indira Gandhi: The story of a Leader and Rani Lakshmibai. History has never lost its significance and it has become indistinguishable with its referents. If history is the signifier, culture and social context becomes the signified. From Historical point of view, the life of both the Queens is analyzed (Lavanya 25).

\section{QUEEN ESTHER}

The main characters in the Novel Hadassah: The girl who became Queen Esther written by Tommy Tenney are Xerxes, Esther, Mordecai, and Haman. Xerxes, the king of Persia, searched for a new queen. Assisted by her cousin Mordecai, the orphaned Jewish maiden Esther was selected to become the new queen. Mordecai won the king's favor by alerting the king to an assassination plot. He warned the king through Esther. The story of Esther from the Bible probably written during the year 480- 450 B.C the novel brings out historical account due to the accurate portrayal of Persian court life and knowledge of Persian customs. The novel, Hadassah the girl

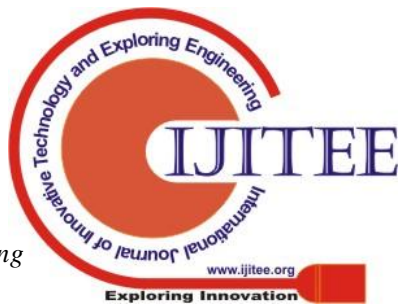


who became Queen Esther talks about Hadassah's childhood life. It was Hadassah's seventh birthday and she was very excited to receive her birthday gift from her mother. When she opened her hands and saw, her mother laid a beautiful gold medallion, nowhere before she has seen such a beautiful medallion. It was the most beautiful gift she had ever received. It's got a star on it which is having a six- pointed edges. That represents the promise Land, the land of Israel. Many years ago, her great, great grand-mother brought this medallion from the promise Land to Persia. As she was sleeping, wearing the star medallion, a group of Amalekite warriors came and killed all the family members and destroyed everything. Hadassah was the only person who got saved from the slaughterers as she was hidden under her bedsheet in the next room. Later she was raised by her elder cousin Mordecai whom she called as Poppa.

Mordecai, a scribe in the King's court became her guardian. Because of the hostile feelings towards the Hebrews by the Amalekite; Mordecai keeps Hadassah hidden until a day she persuades him to allow her to attend a court celebration dressed as a boy. Hadassah is awed by the splendor of the royal court and watches as King Xerxes orders Queen Vashti to walk before the onlookers. When Queen Vashti refuses, she is banished and later killed. Soon Hadassah is caught in a campaign to round up young virgins for the King. Esther's a yearlong preparation for her one night with the King requires all her courage and wisdom. With the fate of thousands of lives in her hands she steps center stage in a drama that changed the course of history for her people.

\section{RANI LAKSHMIBAI}

Rani Lakshmibai is considered as the Joan of Arc of the Indian freedom struggle. She was born in 1835, at Satara in Maharashtra. Lakshmibai was very beautiful, intelligent and brave woman. In her childhood, she was known as Manikarnika. She was lovingly called as Manu at her home. After her Marriage, her name got changed from Manikarnika to Lakshmibai. She was the daughter of Moropant Tambe who was in the service of Peshwa Chimmaji on a monthly salary of rupees fifty. When she was merely a child, she lost her mother, Bhagirathibai. After the death of her mother, her father brought her up with much zeal and autonomy. He injected in her the natural qualities of boldness and courage. She was brought up with great care and was taught horse riding and the use of weapons from Childhood. She was taught reading and writing, mathematics and history. She also learned Persian language.

At the young age of fourteen, she was married to the King of Jhansi, Gangadhar Rao. Jhansi was a small Maratha state. Its geographical location made it very important. Lakshmibai was blessed with a son in 1851. But the child died after three months. The bliss of marriage did not last long. Gangadhar Rao started losing his health and in 1853 he fell seriously ill. Soon Gangadhar Rao adopted a son called Anand Rao, a boy of five years old whose name was changed to Damodar Rao later. The approval letter for adoption was submitted to British government but Gangadhar Rao died before the approval. Instead of giving approval to the adoption, the doctrine of Lapse was enforced by Lord Dalhousie on Jhansi.
Lakshmibai refused to accept the order of the British Government. Though she was very young and not much experienced in matters of the state, she openly declared that she would not hand over the state to the British government. "Mi mahji Jhansi nahidehnar"(I will not give up my Jhansi). She was offered a pension, a palace and the right to keep her personal property and ornaments. Since the petition did not bring any tangible results, she sent a mission to England to represent her case. But it proved to be a cry in the wilderness which made Rani furious.

Jhansi declared an open revolt on June 5, 1857. Rebellious people attacked the British forces and authorities. The followers of Rani Lakshmibai joined the revolutionary forces. They released the prisoners, set fire to the local British court and killed the officers of the British forces. The fort in which the English men had taken shelter was also attacked. The exchange of fire continued till the night. When she heard the British forces were advancing towards the camp, she went up to the top of the house to see the British troops and determinately came down. She mounted the horse to charge and ensued the fight. She received cuts on various parts of her body. The guns of the fort opened fire. The Rani returned to the fort but soon fell from her horse and she died as a brave warrior of the land. She never took a backward step in the battle field but fought till her last breath for her people and the land.

\section{DISCERNMENT AT THE CRUCIAL TIME}

Esther responded to Mordecai's appeal to save the Jews from the cruel plot of Haman that is the King has issued an order to kill all the Jews. When Queen Esther came to know about the massacre of Jews she feels very bad and immediately she sends a letter to Mordecai through Jesse that all the Jews in Susa should prepare themselves for three days fast without eating and drinking. She also along with her maids fasted for three days so that she can be mentally and physical prepared to meet the King. During that time, she said "I will go to the king. And if I perish, I perish." (Tenney pg: 136). But she was quick enough to react on time. Finally, she met the King in his court without his invitation. According to the Persian rule no one should enter the King's court without his permission otherwise that person would be killed. In the case of Esther she risked her life for her tribe without any delay she entered the Kings throne for justice. Queen Esther was lucky enough that she found favour in the eyes of the King and escaped from death. She was not hasty in making decision when the king asked for her wish. She was very wise enough to strategize the things and she requested the King and Haman to come for the first banquet and again she requested for one more banquet to be attended by King and Haman. In that crucial time, she revealed her heart's desire and pleaded for her people's Life. The King was drawn by Esther and made her request come true. Her right decision at the right moment and discernment for the people's cause made her to stand before the King to plead and win over her heart's desire.

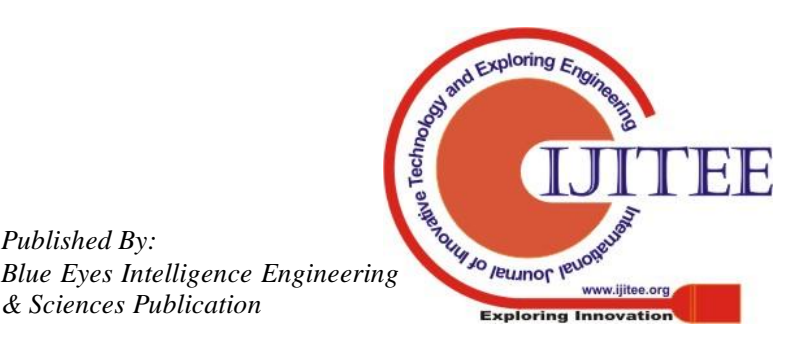


Rani Lakshmibai was never afraid of anyone in her stand to fulfill her appeal for Jhansi. She was focused on achieving her goal. Sir Hugh Rose, who was commanding the British army, demanded for the city to be surrendered with the threat that it would be destroyed. Lakshmibai refused to surrender and went on to defend Jhansi from the Britisher ("News world India").The British bombed the fort on March $24^{\text {th }} 1858$, but were met with heavy fire in return by the Indian army. Rani sent a request to Tatya Tope for help. Hehimself heading an army of 20,000 soldiers reached Jhansi, but were unable to compete the British forces and battle continued. When Lakshmibai realized that Jhansi is going out of her hand, she decided to leave Jhansi and join hands with Tatya Tope and Rao Sahib.The British attacked Kalpi and Lakshmibai and Tatya Tope were defeated. The leaders of this opposition, Lakshmibai, Tatya Tope, Rao Sahib and the Nawab of Banda fled to Gwalior where they joined the Indian forces who were guarding the city. Lakshmibai and her team wanted to retain the Gwalior Fort for its beauty and charm, but they were unsuccessful in trying to convince the rebel leaders in the area to protect Gwalior against the British. On June 17th of the same year, near Phool Bagh in Gwalior, British troops under Captain Heneage fought with Indian forces commanded by Lakshmibai. She dressed herself as a man in a Soldiers uniform, completely armed on a horseback, with her infant son tied to her back, and began attacking the British troops. The British retaliated and Lakshmibai was grievously wounded. Since she did not want her body to be captured by the Britishers, she told a hermit to cremate her. After her death on June 18th 1858, her body was cremated as per her wish. Three days after the death of Lakshmibai, the British captured the Fort of Gwalior.It is evident that Queen Esther and Rani Lakshmibai both had the inner discernment and courage to stand for people in the hours of need and lived a sacrificial life for the cause and betterment of the people. Being women, nothing made them less to achieve their goals.

\section{SIMILARITIES OF LIFE AND PERSONALITY \& RESULTS}

Esther and Lakshmibai's life is similar in many ways. Esther's name before marriage was Hadassah but after marriage it got changed as Esther. Lakshmibai's name before marriage was Manikarnika but after marriage her name changed as Lakshmibai. Esther was raised by Mordecai who took a father's role in her life and Lakshmibai was raised by Moropant. Esther was instructed by her father about how to act and be courageous. She was taught by Mordecai to read and write Hebrew and Persian languages. Lakshmibai was taught by her father about the natural qualities of boldness and courage. She was brought up with great care and was taught with horse riding and the use of weapons from Childhood. Even she was taught by her father to read and write Persian langauge. At the young age Esther was married to Xerxes. Lakshmibai was married to Gangadhar Rao. Both were born from ordinary families but married to a King. Esther and Lakshmibai didn't have a child of their own. Lakshmibai adopted a child named Damodhar Rao. Esther raised the son of Queen Vashti Artaxerxes as adopted son (Hadassah's Covenant). Esther was a brave and Zealous Jewish woman. When she heard about the danger for the tribe of Jews, she couldn't control herself and took a strong decision to fight for her people. She prepared herself for three days without food and water instructing the Jews in Susa also not to eat anything. On the fourth day she made herself prepared to present in front of king Xerxes. Finally, Esther called the King and Haman for the feast. In the second banquet she opened her request for saving the life of Jews. In the end she was successful enough to make her request granted by the King, killingfive hundred men and ten sons of Haman.

In the case of Lakshmibai, it was the time when women wore veils whereas she continued practicing horse riding, shooting, wrestling and all the martial arts within the fort. She used to discuss serious political matters with her father Moropant. Dalhousie declared that Jhansi should be annexed with the British Empire. Lakshmibai opposed the Britishers stating, "I will not give my Jhansi at any cost" ("Daily hunt"). India's First war of Independence was fought in 1857. As the British army advanced towards Jhansi, Rani Lakshmibai organized her army. She dressed up like a soldier, tied Damodar, her son, to her back and led her army against the Britishers. She fought courageously till her last breath. She was badly wounded and when she was about to die, she said, "Let no Britisher touch my body" ("Daily hunt"). She breathed her last near Gwalior Fort. Her companions performed her last rites. No Britisher dares to touch her living or dead.

\section{CONCLUSION}

Esther and Lakshmibai fought for their own people with much bravery and patriotic zeal for their nation. While being ordinary female or Queen, they never considered any of the odd factors in their life.They faced many struggles and challenges, but they stood firm and discern till the end. Thus, both Esther and Lakshmibai's nature and physical traits match in many aspects. In the end Queen Esther was victorious in saving her people from the cruel enemy, Haman and from there starts the festival of Purim. In the case of Rani Lakshmibai, she fought against the enemy till her last breath resisting them to conquer Jhansi. She was the first initiator of freedom fight movement in India which took some long years to get victory. Even after her death the freedom struggle continued and Indians could achieve their victory which is celebrated as Independence Day. Hence, it is clear that, Esther and Lakshmibai esteemed their power without giving up their determination for the cause. Both stood for their right to live in their own land. Even though the enemy had plan to trap the situation and to take an over hand, their zeal and love for the people made both of them keep on struggling to attain success. Therefore, they proved themselves to be the real heroines for the people.

\section{REFERENCES}

1. Tenny, Tommy and Olsen Andrew Mark. Hadassah:One Night with the King. USA: Bethany house, 2004. Print.

2. ---, Hadassah: The girl who became Queen Esther. USA: Bethany house, 2005. Print.

Published By:
Published By: Engineering \& Sciences Publication 
3. ---, The Hadassah Covenant. USA: Bethany house, 2005. Print.

4. ---, Finding favor with the King. USA: Bethany house, 2003. Print.

5. Anderson, Hugh. Historians of Israel. London: Lutter worth press, 1970. Print.

6. Bassnett, Susan. Comparative Literature a critical Introduction. USA: Blackwell, 1993. Print.

7. Berg, S.B. The book of Esther. Missoula, Mont. Scholars Press, 1979. Print.

8. Dasgupta, Shahana. Rani Lakshmibhai The Indian heroine. India: Rupa Co, 2002. Print.

9. Clines, David J.A. The Esther Scroll. England: JSOT Press, 1984. Print

10. Collins. The Collins Atlast of World History. Switzerland: British Library Cataloguing Publication, 1987. Print.

11. Cooley, Thomas. Back to the Lake. USA: Norton company, 2012. Print.

12. Dorothy, Charles V. The Books of Esther. England: Sheffield Academic Press, 1997. Print.

13. Dalley, Stephanie. Esther's Revenge at Susa, USA: Oxford University press, 2007. Print.

14. Dawson, Alma and Connie Van fleet. African American Literature. Chennai: Mutivista Global ltd, 2005. Print.

15. Friedman, Elliott Richard. Who Wrote the Bible. New York: Summit books, 1978. Print.

16. Gabel, B. John., Wheeler and Charles B. The Bible as Literature An Introduction. New

17. York: Oxford University Press, 1986. Print.

18. Howard, $\mathrm{M}$ and David Jr. An Indroduction to the Old Testament Historical Books. Chicago: Moody, 1993. Print.

19. Handa, Sushil. Fifth veda entrepreneurs. Larger than life, Rani Laxshmibai. Web. 20 Sept. 2018.

20. Kay. Allison. Literary and Empirical Reading of the Books of Esther. New York: Peter Lang Publishing, 2002. Print.

21. Keller, Werner. The Bible as History. London: Hodder and Stoughton, 1961. Print.

22. Kent, Foster Charles. Israel's Historical and Biographical Narratives. New York: Charles Scribner's Sons, 1914. Print.

23. Lambton, Ann. K. S. and Bernard Lewis. The Cambridge History of Islam. London: Cambridge University press. 1970. Print.

24. Levenson, Jon D. Esther A Commentary. London: SCM press Ltd, 1997. Print.

25. Lavanya, S. Critical Perspective on Postcolonial Literature.NewDelhi: Sanbun Publishers, 2016. Print.

26. Lyles, Ron. Bible Book Study Commentary, Ezra Nehemiah, Esther. Tennessee: Sunday school board, 1995. Print.

27. "Learn.culturalindia.net" rani-lakshmibai, Web. 26 Nov. 2018.

28. Media Text Books. Lesson-15.pdf, Rani Laxshmibai. Web. 20 Sept. 2018.

29. Merrill, Eugene. An historical survey of the old testament. New Jersey: The craig press, 1966. Print

30. "Mallick, David. "An Introduction to the Book of Esther". 14 June. 2004. Web. 26 Nov. 2018.

31. Moore, Carey. A Esther. Ab7b. Garden city, N.Y: Double day, 1971. Print

32. Miles, Jack. GOD a Biography. New York: Vintage house, 1995. Print.

33. Paton, Lewis. Bayles Critical and Exegetical Commentary on the Book of Esther. Morrison and gibis 1td, 1964. Print.

34. Rajaram, Kalpana. Facets of Indian Culture. India: Spectrum books P ltd, 2015. Print.

35. "Ranilakshmibai"dailyhunt.in, Newspaper Web. 25. Oct. 2018.

36. "Rani-lakshmibai" Newsworldindia.in, Web. 25. Oct. 2018.

37. Robinson, H. Wheeler. The Old Testament. London: Hodder and Stoughton, 1949. Print.
38. Schuster, Ignatius. Illustrated Bible History. India: St. Paul Publications, 1963. Print.

39. Sharma, A.P. 20 Great women of India. NewDelhi: Prashant Publications, 2000. Print.

40. Swain, James Edgar. A History of World Civilization. India: Eurasia Publishing house, 1984.

41. "Tommy Tenney." Wikipedia, The Free Encyclopedia. Wikipedia, The Free Encyclopedia, 4 Jul. 2018. Web. 15 Aug. 2018.

42. "The Editors of Encyclopaedia Britannica" Lakshmibai Encyclopedia Britannica, inc. Web. 26. Nov. 2018.

43. "Thefamouspeople.com" rani-lakshmibai, Web. 26 Nov. 2018.

44. "Thequint.com explainers" Rani-Lakshmibai, life history. Web. 26 Nov. 2018

45. The story of Rani-lakshmibai, tbsplanet.com. Web. 26 Nov. 2018.

46. Thoburn, Stanley. Old Testament Introduction. India: The Christian Literature society, 1961. Print.

47. Trask, R.L. Language and Linguistic. New York: Routledge, 2005. Print.

48. Wells, H.G. History of the World. India: Atlantic Publisher and Distributor, 1994. Print.

49. Wirth, Hana - Nesher and Michael P. Kramer.Jewish American Literature. UK: Cambridge university press, 2003. Print.

50. Woodruff, Stephen B. Esther. Philadelphia: Mason Crest Publishers, 2009. Print.

51. Vincent, Daniel. "Biblical Folklore". Concept publishing company. New Delhi: 2007. Print 